\title{
Acute Kidney Injury after Ingestion of a Native Southeast Asian Fruit as a Complementary Remedy
}

A 72-year-old Indonesian male presented with nausea and vomiting 1 day after ingesting 3 bottles (total volume of 1 litre) of homemade juice from a palm-sized ovoid green fruit (Fig. 1). The sour fruit was harvested from a common native garden plant, and was recommended to him as a traditional remedy for his hypercholesterolaemia.

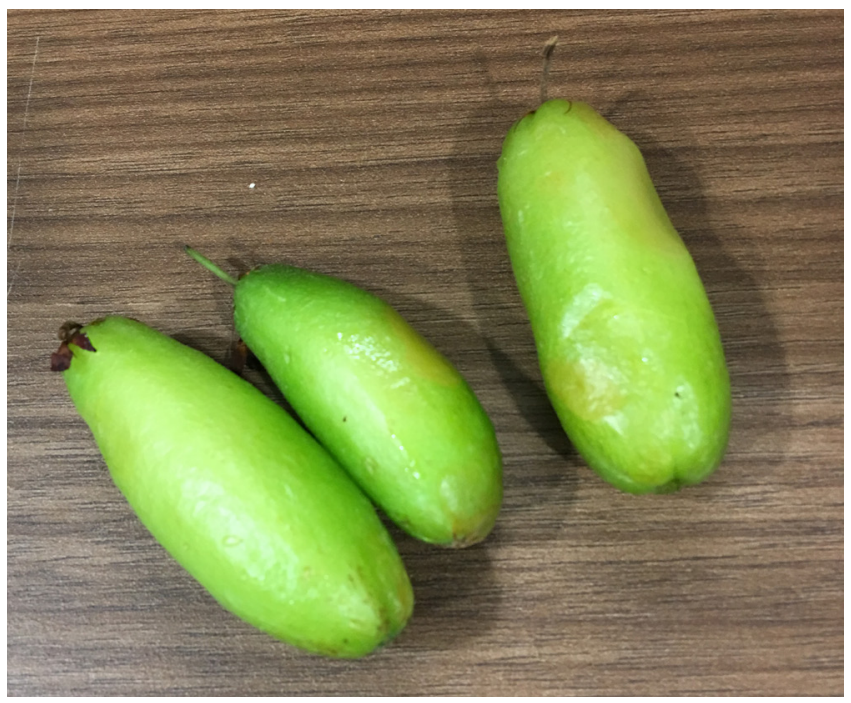

Fig. 1. Palm-sized ovoid green fruit

Our patient has a background of diabetes mellitus, hypertension and hyperlipidaemia. As he was not a resident in Singapore, there were no available records of baseline serum creatinine and baseline urine albumin/ protein levels. Patient however claimed that he was previously told by his general practitioner in Indonesia that he did not have any renal impairment. He was not known to have ischaemic heart disease or congestive cardiac failure. His chronic medications comprised Atenolol, Fenofibrate and Gliclazide.
On admission, he did not have fever, abdominal pain, diarrhoea, gross haematuria or frothy urine. He was hypertensive with blood pressure of $181 / 87 \mathrm{mmHg}$. Patient was alert in mentation and clinically euvolaemic -lungs were clear on auscultation and there was no peripheral oedema. Jugular venous pressure was not raised. Bladder was not palpable. Patient was not oliguric and had urine output of $800-1000 \mathrm{ml}$ per day.

Investigations showed a markedly elevated serum creatinine of $1146 \mu \mathrm{mol} / \mathrm{L}$. Urinalysis did not identify casts or microscopic haematuria. However, there was proteinuria as Urine Protein Creatinine ratio on admission was $0.80 \mathrm{~g} / \mathrm{g}$. Anti-nuclear antibody, antidsDNA, anti-neutrophil cytoplasmic and anti-glomerular basement membrane antibodies were negative. C3 and $\mathrm{C} 4$ were within normal ranges. He did not have cytopenias or peripheral eosinophilia and urine eosinophils were not detected. Doppler ultrasonography of the kidneys was unremarkable. Bilateral kidneys were $10 \mathrm{~cm}$ in length and no hydronephrosis was detected. The patient declined a kidney biopsy.

Given the above clinical presentation and the fruit presented, what is the likely cause for his acute kidney injury?
A. Sepsis
B. Pre-Renal from Gastrointestinal Losses
C. Hypertensive Emergency
D. Oxalate Nephropathy
E. Obstructive Uropathy

Clinically, patient is euvolaemic and there is no evidence of sepsis. Hence, A and B are unlikely. While the patient is hypertensive, the degree of hypertension and absence of other symptoms (especially neurological) that were suggestive of Hypertensive Emergency made the answer $\mathrm{C}$ unlikely. Answer $\mathrm{E}$ is unlikely as ultrasound imaging of the kidneys and bladder did not 
Table 1. Trend of investigations during admission and post-discharge

\begin{tabular}{|c|c|c|c|c|c|c|c|c|}
\hline Labs & Admission & D2 & D4 & D6 & D9 & $\begin{array}{l}1 \text { week post- } \\
\text { discharge }\end{array}$ & $\begin{array}{l}5 \text { months post- } \\
\text { discharge }\end{array}$ & $\begin{array}{l}1 \text { year post- } \\
\text { discharge }\end{array}$ \\
\hline $\begin{array}{l}\text { Urea } \\
(\mathrm{mmol} / \mathrm{L})\end{array}$ & 38.1 & 42.0 & 27.1 & 23.6 & 20.8 & 17.4 & 6.2 & 5.8 \\
\hline $\begin{array}{l}\text { Creatinine } \\
(\mu \mathrm{mol} / \mathrm{L})\end{array}$ & 1101 & 1146 & 659 & 452 & 374 & 208 & 99 & 88 \\
\hline $\begin{array}{l}\text { Sodium } \\
(\mathrm{mmol} / \mathrm{L})\end{array}$ & 134 & 138 & 146 & 141 & 139 & 136 & 144 & 141 \\
\hline $\begin{array}{l}\text { Potassium } \\
(\mathrm{mmol} / \mathrm{L})\end{array}$ & 4.4 & 4.3 & 3.5 & 3.9 & 3.8 & 4.0 & 3.9 & 3.6 \\
\hline $\begin{array}{l}\text { Chloride } \\
(\mathrm{mmol} / \mathrm{L})\end{array}$ & 101 & 104 & 102 & 98 & 100 & 102 & 110 & 110 \\
\hline $\begin{array}{l}\text { Bicarbonate } \\
(\mathrm{mmol} / \mathrm{L})\end{array}$ & 15.9 & 15.0 & 26.8 & 27.7 & 25.5 & 23.7 & 24.9 & 26.9 \\
\hline $\begin{array}{l}\text { Calcium } \\
(\mathrm{mmol} / \mathrm{L})\end{array}$ & 2.25 & & & & & 2.30 & 2.34 & \\
\hline $\begin{array}{l}\text { Phosphate } \\
(\mathrm{mmol} / \mathrm{L})\end{array}$ & 2.45 & & & & & 0.95 & 1.10 & \\
\hline $\begin{array}{l}\text { Uric Acid } \\
(\mu \mathrm{mol} / \mathrm{L})\end{array}$ & 631 & & & & & & & \\
\hline $\begin{array}{l}\text { Urine Protein: Creatinine } \\
\text { Ratio }(\mathrm{g} / \mathrm{g})\end{array}$ & 0.80 & & & & & & 0.11 & 0.10 \\
\hline
\end{tabular}

yield evidence for obstructive uropathy. The patient's clinical presentation after ingestion of the above fruit is consistent with D-Acute Oxalate Nephropathy. Fig. 1 shows the fruit of Averrhoa bilimbi, a cousin of the starfruit (Averrhoa carambola) and from the Oxalidaceae family. The plant is native to tropical areas such as Southeast Asia. The fruit is believed by certain communities in Southeast Asia and South Asia to improve obesity, hypertension and diabetes. ${ }^{1}$ As undiluted juice of this fruit contains concentrated oxalic acid, ingestion can lead to elevated serum oxalate and deposition of calcium oxalate crystals in renal tubules. This damages the renal tubules and interstitium, causing acute kidney injury and over time, interstitial fibrosis. ${ }^{1,2}$

Acute oxalate nephropathy secondary to ingestion of Averrhoa bilimbi has been described in India, ${ }^{1,2}$ but seldom in Southeast Asia. Envelope-shaped oxalate crystals were found in urine microscopy while kidney histology showed intratubular polarisable calcium oxalate crystals with acute tubular necrosis and interstitial inflammation. ${ }^{1}$ Ultrasound of the kidneys is usually unyielding in oxalate nephropathy as seen in observational studies. ${ }^{3,4}$ Severe acute kidney failure was not uncommon and transient renal replacement therapy was required in $60-70 \%,{ }^{2}$ but prognosis was generally good with renal recovery within $2-8$ weeks. ${ }^{1}$

Oxalate nephropathy is uncommon and may be due to primary or secondary hyperoxaluria. ${ }^{3}$ Primary hyperoxaluria is a rare inborn error of glyoxylate metabolism characterised by the overproduction of oxalate. Secondary hyperoxaluria is more common and is usually the result of increased oxalate intake or absorption, reduced intestinal oxalate degradation or reduced renal excretion. ${ }^{3}$ A systematic review of secondary oxalate nephropathy between 1950 and 2018 found that enteric hyperoxaluria was the most common cause. Increased dietary oxalate intake was attributed to high-dose Vitamin C supplements, starfruit (Averrhoa carambola), peanuts and rhubarb. ${ }^{3}$ Unlike the good 
prognosis for acute kidney injury from Averrhoa bilimbi, ${ }^{2}$ this systematic review noted that $55 \%$ required dialysis on presentation and 58\% remained dialysis-dependent.

The classical history of recent ingestion of fresh concentrated Averrhoa bilimbi fruit juice likely led to acute kidney injury in our patient.

While inpatient, he was initiated on supportive renal replacement therapy on Day 2 of admission. Additional sessions of haemodialysis were further performed on Day 4 and 6 of admission. His renal function continued to improve without dialysis and we were able to wean him off renal replacement therapy. He was subsequently discharged and renal function was monitored closely outpatient. Table 1 shows the trend of patient's renal function, electrolytes and urine protein creatinine ratio during admission and post-discharge. Five months later, patient's creatinine levels had improved to $99 \mu \mathrm{mol} / \mathrm{L}$ and proteinuria resolved (urine protein creatinine ratio $0.11 \mathrm{~g} / \mathrm{g}$ ). Blood pressure was also well controlled at $124 / 65$. No further renal replacement therapy was required.

\section{REFERENCES}

1. Mahamoodh Z, Vijayan S, Jojo A. A case series on Averrhoa bilimbi induced acute oxalate nephropathy; an experience from a tertiary center in Kerala, India. J Nephrol 2018;7:296-300.

2. Bakul G, Unni VN, Seethaleksmy NV, et al. Acute oxalate nephropathy due to 'Averrhoa bilimbi' fruit juice ingestion. Indian J Nephrol 2013;23:297-300.

3. Lumlertgul N, Siribamrungwong M, Jaber BL, et al. Secondary Oxalate Nephropathy: A Systematic Review. Kidney Int Rep 2018;3:1363-72.

4. Buysschaert B, Aydin S, Morelle J, et al. Etiologies, Clinical Features and Outcome of Oxalate Nephropathy. Kidney Int Rep 2020;5:1503-9.

Tung Lin Lee, $M B C h B(E d i n), M R C P(E d i n)$,

Cynthia C Lim, MMed (S'pore), MRCP (Edin), FRCP (Edin),

Chieh Suai Tan, MBBS, MRCP (UK), FAMS

Department of Renal Medicine, Singapore General Hospital

Address for Correspondence: Dr Lee Tung Lin, Department of Renal Medicine, Singapore General Hospital, Academia Level 3, 20 College Road, Singapore 169856

Email: tunglin.lee@mohh.com.sg 